\title{
The transformations of the peripheral urban form in Brazilian listed heritage coastal cities and their morphological typologies: Classification and concepts
}

\author{
Ramon Fortunato Gomes \\ Faculdade de Arquitetura e Urbanismo. Universidade de Brasília. Instituto Central de Ciências \\ (ICC) Norte. Brasilia, DF, Brazil \\ E-mail: ramon.fortunato.gomes@hotmail.com
}

\begin{abstract}
This paper presents the results of my $P h D$ research in architecture and urbanism, which analyzes an urban form and its use as a territorial planning tool. The object of study was the protected historic cities listed on the Brazilian coast, which have restrictions on building construction. These cities are influenced by urban flows, the impact of the metropolitan dynamics, and contemporary transformations. The research discusses the rigidity of the building legislation in the urban perimeter of these cities, while urban transformations and informal growth take place in peripheral areas in varied forms, types and arrangements. It aims to identify, classify and conceptualize the morphological types that appear as urban occurrences and consolidate as dispersed informal nuclei. Such urban occurrences are due to the building restrictions, the lack of territorial planning, and the contemporary globalized model of life, which shapes social inequality in urban expansion. The research methodology consisted of a perimeter survey of the 27 heritage listed cities on the Brazilian coast, according to the parameters obtained by New Brazilian Forest Law (12.651/2012) and Brazilian Urban Land Parceling Law (Law 6.766/1979). Also, imagery collected by Google Earth was used to identify urban formations that deviate from legislation, similarly to the object of study. As a result, 16 types of urban forms were classified, which consolidated as nuclei of dispersed formations and were linked to an informal urban structural network. Also, territorial planning guidelines were designed, using the analysis of urban forms as a tool for urban transformation.
\end{abstract}

Keywords: Heritage cities, Brazilian coast, urban morphology, urban occurrences, informal nuclei

\section{Introduction}

The presented study has as object of research the informal urban form of the peripheral areas in the protected historic urban settlements of the Brazilian coast and their relation with the urban territorial planning. It takes as object of research the historical cities located in the Brazilian coast, proclaimed by the Instituto do Patrimônio Histórico e Artístico Nacional (The National Institute of Historic and Artistic Heritage- IPHAN) protected historic settlements. They are represented by 27 cities between the North and South regions, where five of these are proclaimed World Heritage by United Nations Educational, Scientific and Cultural Organization-UNESCO.

Considered in the research as buildingrestrictive territories, they have a rigid legislation under its territories with the objective of diminishing and stopping the urban growth. On the other hand, phenomenon or impacts that occur in the peripheral areas of these cities, under the form of informal growth, can be observed. Thus, this study inquires analyzing the urban formations that come 
up from informal occupancy. As its base, the building legislation about the division of the urban grounds and gives other providences, as determined by the Law 6766/79, and the New Brazilian Forest Code, Law 12651/12, that displays the protection of native vegetation $[\ldots]$ and gives other providences.

Is considered informal, all the occupancies, center parts, constructions that fixed in the territory for research purposes, without the construction licensing, or that do not meet the basic requirements of the Law. Characterized by large or absence of blocks; irregular tracing with damages to circulation; absence of free areas, squares, public and institutional equipment, infrastructure and paved thoroughfare; beginning of constructions in unstructured divisions; occupancies in sandbanks, beaches, riparian forests, river courses and groves; deforestation; invasions and privatization of areas of public property.

Were named as urban occurrences and defined as urban centers that come up from occupancies or unlicensed plans and grow informally in the urban ground. "Excites an uncontrolled, informal and even illegal growth, that does not meet any economic development" (Panerai, 2006). The study also shares the idea of non-exclusive phenomena of urban formations that emerge from the disorder or from the lack of urban planning, but from a formula of urban control made under a legal basis that prevents the city from "growing with grace, justice and beauty" (Rolnik, 1997).

There is where one of the most interesting aspects of the law lives: apparently, it works as a type of mold of an ideal or desirable city. [...] But, when establishing permitted or prohibited forms, it also defines under and out of the law territories, or, in other words, configures regions of full citizenship and regions of limited citizenship - translated by Author. (Rolnik, 1997).

The set of urban occurrences configure in the object of study the form of periphery. Grouped or isolated, dispersed or condensed, they have urban and rural character and are directly related to the urban structure of the cities.
They are urban forms with a particular way of occupying the Brazilian territory in its core. It was important to understand and conceptualize two reference points in the research, the structure and the concepts of the urban form and the historic city of the Brazilian coast as protected patrimony.

\section{Formal and Historic Aspects of the Urban Plans}

The urban plan is made of buildings, uses and their distribution in the urban space. It can be conceived through urbanistic planning followed by rigorous planning criteria or by vernacular crafts developed by the culture of generations. The urbanistic plans are conceptions and construction or modifications of cities projects. They organize the cities' tracings, the position of the main buildings and direct the form of the edifications and the urban growth. This way of thinking the space and transforming it was originated in the history of the cities which were established based on the commercialization and production of exceedance. The development of the writing and of the sciences, the control of the labor force, the technological capacity of transporting raw material, the domain of the natural space and the manufacture of utensils pointed to an urban revolution that gave birth to new ways of building a city, classified in its differences and functions. (Morris, 2004).

The irregular plan, called organic, is characterized by presenting an apparent irrationality on the implantation of the building. It is not orderly, with narrow, sinuous circulations, giving the sensation of a labyrinth. The result of this plan reflects the inexistence of a previous planning with wide and planned thoroughfares. Representative in the Islamic cities, in the cities with the Roman origin organic growth, in medieval cities, in the burgs of military bases that acquired commercial functions and in the cities that grew from existing villages (Morris, 2004; Carvalho, 2003).

The orthogonal plan is named after: rectangular, hypodamic, grid point and chessboard. They are plans where the streets cross each other in perpendicular angles, 
creating the sensation of order in the space. Its origin comes from the history of the formal Greek cities, which main characteristics were the relation established between its main buildings, the acropolis, the wall, the agora, the suburbs, the areas for recreation, culture, religion and the port that made the industrial section of the docks (Morris, 2004). The know-how of building cities mastered by the Greeks was transferred, by Vitruvius, in its conception of ideal city of circular plan, meeting the standards in relation of harmony, regularity and determination (Carvalho, 2003). These plans are presented repeatedly in cities conceived along the XVIII and XIX centuries in the colonization, mainly by Spaniard and Portuguese ones.

The regular plan is recovered in the renaissance period through the geometrical and radial plans, named radio centric plan. It is characterized and idealized around central points, such as markets, churches, monasteries and squares. It presents roads formed by streets that come from the center and thoroughfares that make circles, far from the center point. It is noticeable that the regular tracing of the bigger streets surrounding the centers superpose the old walls that were demolished in order to make the population growth in the medieval cities possible. Thus, new walls could be built far from the center to protect the medieval city. We can highlight the creators of the regular plan: León Battista Alberti (1404-1472), with contributions on the planning area, More (1478-1535) presenting the geometrical city in Utopia, Vincenzo Scamozzi (1552-1616) developing the formal balance of the design without presenting an absolute symmetry and putting his ideas into practice, such as the city of Palma Nova in Italy (Goitia, 2001). Also, with traces of the regular plan, there were the baroque cities, characterized by the ideal plans and by the embellishment of the cities. The renaissance period, "when the planning of the cities started being faced as part of the discipline of architecture and had to follow the same mathematical criteria of rigor of the mathematical base" (Teixeira, 2012).

The linear plan, organized along a passage, such as streets, avenues or seashore. They are plans that bring difficulty on the transportation and communication between opposite points due to their distance. And the juxtaposed plan, characterized by the presence of different arrangements superposed in a city. They are commonly present in cities with a bigger history of urban transformations, where the different urban plans of the territory are represented by distinct moments of urban growth (Morris, 2004; Carvalho 2003).

Besides the five plans of reference on urban morphology, Carvalho (2003) contributed and conceptualizes, in his studies, other four morphological types. The classic plan, where there is a mixture between the orthogonal and the regular plans, as the example of the GrecoRoman, renaissance and baroque cities. The garden plan, made of examples of rural tradition as the garden cities and urban dwellings. The modernist plan, represented by the modernist planned cities, having as main reference the models of La Corbusier. And the urban-bucolic plan, represented by urban fragments on the countryside, making a disperse city of closed condominiums and suburbs, reflecting the current city.

\section{The Historic City of the Brazilian Coast, Growth and Control}

They are urban centers that that had their origins on the Portuguese city plans. They are born from two types of conceptions, one connected to the spaces of vernacular structures and other connected to the mathematical and geometrical bases. Built in different historical and geographical contexts, it is possible to find, in their plans, the roughest components and the components of the most informed technique (Teixeira, 2012). The Brazilian cities of the Portuguese colonization period had their importance as Brazilian cultural and artistic heritage preserved through preservation policies of the historic heritage.

They are protected through restrictive building laws and standardizations that put them as important historic cities, guaranteeing the structural, formal and landscape integrity of these urban settlements. They were potentialized as places, meaning and image, recognized as cultural, touristic and leisure 
territories, in spaces of natural value such as beaches, rivers, dunes, lagoons, bays and native forests, pervading historic-valued houses.

Recognized as tourism territory, the speculation of the Protected Urban Settlements provided other dynamics of populational, consumption and estate fetish fluxes. Urban dynamics and practices of use and consumption put the conservation and preservation of the cultural and natural heritage at risk. It is possible to observe that they are cities that experience the full populational growth (Instituto Brasileiro de Geografia e Estatística, 2016). They became attractive to tourism, service, acquisition of a second house by vacationers and urban speculators demands.

They experience the degradation and deterioration of the territory problems, caused by the unjustified and excessive of its spaces in phases of exploration, engagement of the society, economic development, consolidation and stagnation. They take cities of touristic potential to their declining or rejuvenation, according to the ordering, territorial and touristic planning (Butler, 1980). They foment a new form of city, made of informal occupations. It is understandable that the growth of the peripheric city in informal cores is not exclusive to the protected urban settlements of the Brazilian coast, but the size of the phenomenon in them is intensified by the populational fluxes, by the restrictive laws and by the demand of consumption of the city as an object of tourism and leisure. The diffuse, scattered, multi-cored growth is a phenomenon that is present and characteristic of the contemporary cities, where the city seems to dilute through the territory (Reis, 2006).

The identification of the peripheral urban plans in the historic cities of the Brazilian coast was the main objective of this study. Its typologies and classifications characterized by the explosion of informal and irregular urban plans. With references on the study of the urban plans, and its bases on preservation and urban development, the study can help the identification of the urban occurrences in the peripheral areas of the protected urban settlements of the Brazilian coast.

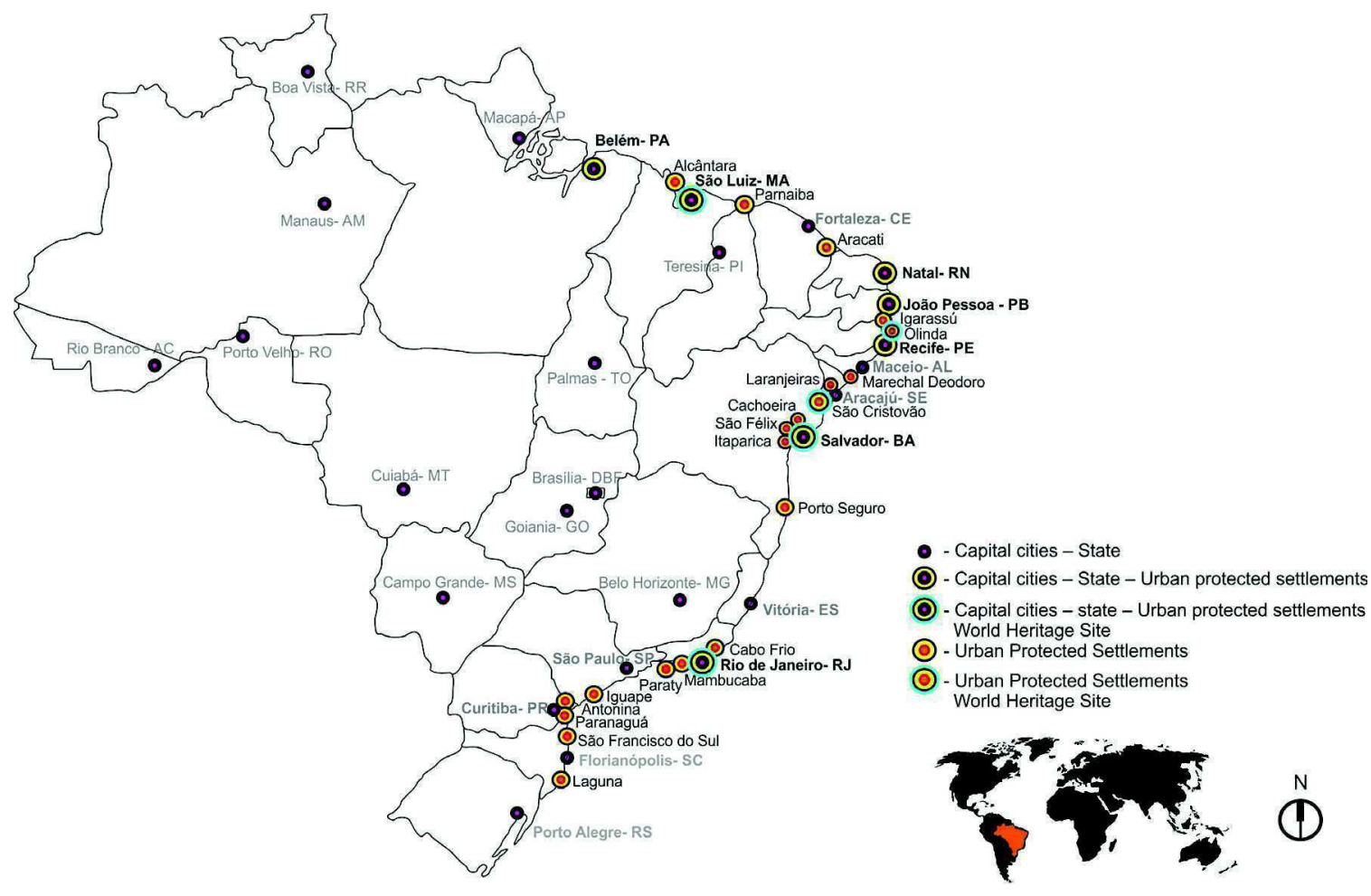

Figure 1.

Urban Protected Settlements of the Brazilian Coast - Object of study. 


\section{Methodology}

The methodological process was built from the definition of the object of study and in the affirmation: "The building laws influence in the peripheric and informal growth of the city". With a look upon the historic city of Paraty, in the southern coast of the state of Rio de Janeiro, we can notice a city growing in peripheric urban occurrences in a disordered way, out of the building parameters.

With the building legislation, restrictive and preservationist, the peripheric areas were not contained. It was possible to observe that the phenomenon of the urban occurrences was related to the application of the building laws. In this direction, the cities that had their behavior through the building law like Paraty's were identified as objects of study.

The protected urban settlements located on the coast, bays or canals with direct connection to the sea became the object of study, making a total of 27 cities on the Brazilian coast, from North Belem (PA) to South Laguna (SC) (IPHAN, 2016; UNESCO, 2017), (figure 1).

The method of identification and classification of the urban occurrences happened through visualization of air images on Google Earth Pro and conceptualized by the fragmentation of the plan in structures of articulation, to look for answers to the observations of the study.

Thus, it is noticeable that similar urban plans are repeated in the peripheric areas in the object of study.

They are urban formations characterized by the irregularity in the plans and in the implantation of the site.

To collect images of irregular urban formations, the observation and gathering of images was made, based on the urbanistic and preservation parameters defined by the Law $6766 / 79$ and by the Law $12651 / 12$.

Used as a method of image capture, the "scan", in which the municipality is divided into quadrants and after is subdivided and scooped with Google Earth Pro, allowing the visualization, the collection, the selection and the classification of informal urban forms.

\section{Measurement and analysis}

This paper presents as result a set of urban forms analyzed to the formation of peripherical areas of the protected historical settlements of the Brazilian coast. They were ordered in tables, classified in 16 types of urban forms and arranged in 4 groups.

Group I (G.I): Irregular occupations that use the structures and the environmental resources for the installation of residential groupings. They are out of the urban order, Law 6766/79, Arts.2nd, 3rd, 4th and 5th, and Law $\mathrm{n}^{\circ}$ 12.651/12, Art. $4^{\circ}$, (figure 2).

Group II (G.II): Occupations that grow in irregular arrangements, taking up free spaces in their entirety. They are common in traditional communities or cores in development process. They are out of the urban order and incur in the articles, Art. 2nd; 3rd and 4th of the Law 6.766/79, and Art. 4th of the Law n ${ }^{\circ} 12.651 / 12$, (figure 3).

Group III (G.III): Urbanistic projects implanted without license or consent of the public administrators. They are characterized by the absence of public and leisure areas. They are out of the urban order and incur in the articles Art. 2nd; 3rd; 4th and 5th of the Law 6.766/79 and Art. 4th and 7th of the Law $\mathrm{n}^{\mathrm{o}}$ 12.651/12, (figure 4).

Group IV (G.IV): Occupations that grows in multiple and diversified arrangements, consisting in different types of urban occurrences. They are types of intervention and incur in the articles: Art. 3rd; 4th and 5th of the Law 6766/79 and in the Art. 4th of the Law no 12651/12, (figure 5).

\section{Conclusion}

This article presents the discussion about the building legislation on its restrictive aspects and consequences to the urban growth. The article also allows the identification of new urban forms and settings that are similar to the ones of the old cities, approaching the illegality over the protected settlements of the Brazilian Coast. Self-constructed; Standardized into preliminary plans; planned to be beautiful; organic or confused; multiple; their differences 
Figure 2.

Urban Occurrences, Group I.

Type: Strangulation of watercourses and springs.

\section{Definition:}

Urban structures that extend over the protection zone of watercourses through urban growth tend to eliminate the native vegetation at the riverside protection areas, causing the strangulation of the spring. They are caused by urban pressures in all directions of the stream bed, presenting the channelization and the extinction of water volume as consequences.

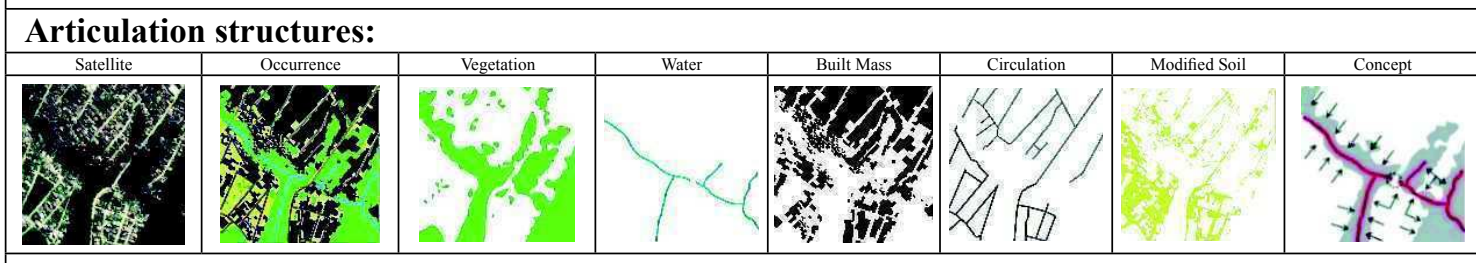

\section{Definition:}

Type: Large structures

Buildings and morphological structures of major impact, located in areas of permanent preservation and native vegetation. They use the existing roads and are characterized by producing extensive areas of waterproofing in the soil, with building blocks, courtyards, accesses, circulation and paving. They cause impacts on the environment and city landscape. Expands in the territory, modifying the soil and using preservation areas and natural resources of the environment.

Articulation structures:

\begin{tabular}{|c|c|c|c|c|c|c|c|}
\hline Satellite & Occurrence & Vegetation & Water & Built Mass & Circulation & Modified Soil & Concept \\
\hline & & & & & & & \\
\hline
\end{tabular}

\section{Definition:}

Precarious structures of territorial occupation. Follows river canals as articulated soil base. Urban growth is consolidated paths in parallel to the channels, breaking limits on native vegetation. This sort of occurrence enables the urban density, making the proper infrastructural implementation more difficult, resulting in consequences to the environment such as disposal of waste in the soil and the discharge of sewage into the canals.

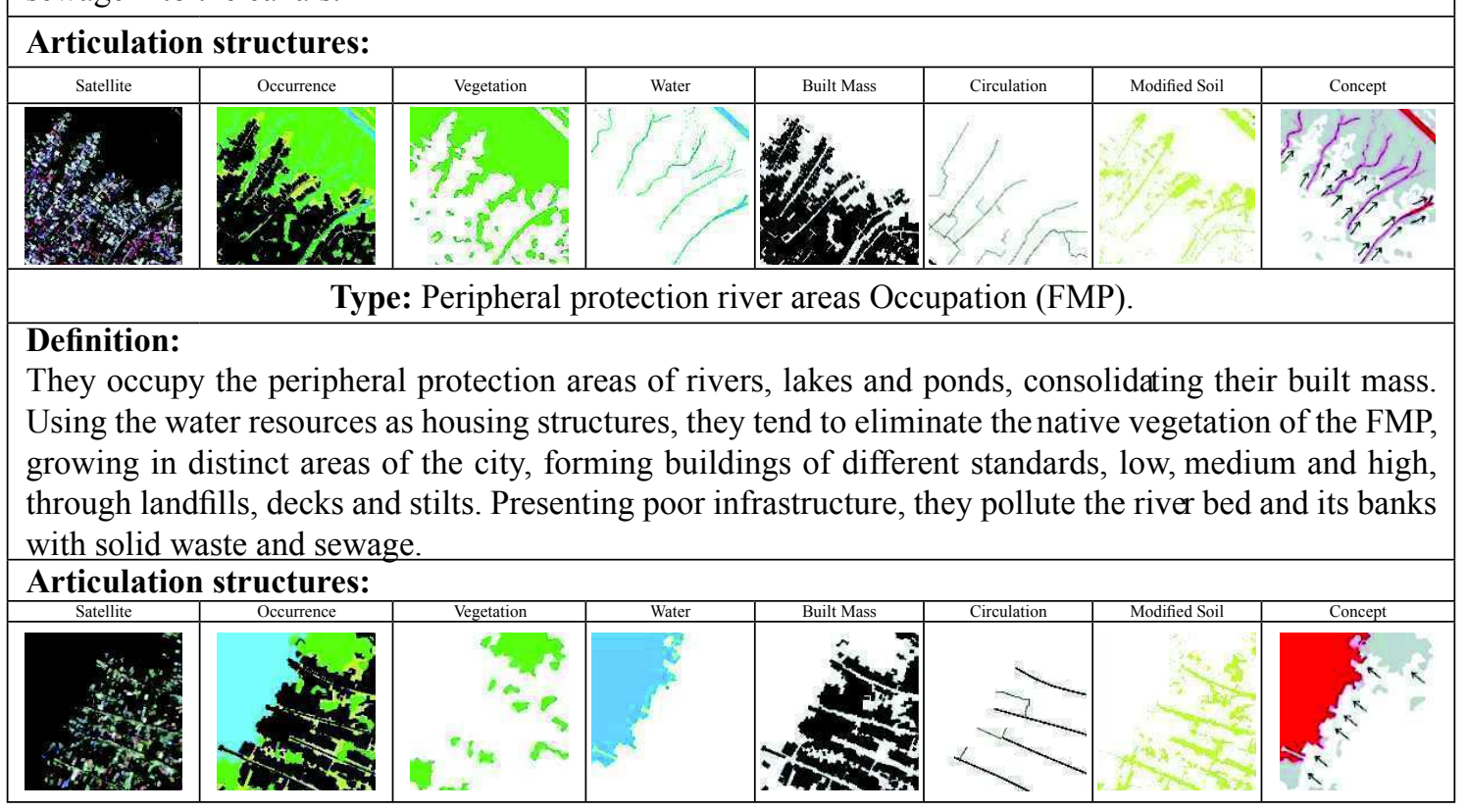




\section{Type: Hills occupation}

\section{Definition:}

Urban structures that extend from the urban tissue through different sorts of circulation accesses and distributed in the topography of the site. Present lower density of built mass and significant precarious urban infrastructure as it distances from the consolidated urban tissues moving upon to the site. It can be observed that the urban growth is restrained by places with extensive difficulty of access, opening paths into more accessible areas on the topography of the site, occupying new plateaus. They are mostly formed by slums, condominiums, farms and facilities related to tourism and leisure.

\begin{tabular}{|c|c|c|c|c|c|c|c|}
\hline \multicolumn{2}{|c|}{ Articulation Structures: } \\
\hline Satellite & Occurrence & Vegetation & Water & Built Mass & Circulation & Modified Soil & Concept \\
\hline & & & & & & \\
\hline
\end{tabular}

Type: Mangrove occupation

\section{Definition:}

They are urban structures sorted by advancing over mangroves, through landfills or stilts. They are consolidated according to the natural mangrove drawing, guided by the site contour. As the urban tissue moves away from the mangrove, an extensive density of soil occupation can be observed. Its formation brings traditional characteristics of populations and communities of native origin that uses the mangrove's natural resources as livelihood.

\section{Articulation structures:}

\begin{tabular}{|c|c|c|c|c|c|c|c|}
\hline \multicolumn{2}{|c|}{ Articulation structures: } \\
\hline Satellite & Occurrence & Vegetation & Water & Built Mass & Circulation & Modified Soil & Concept \\
\hline & & & &
\end{tabular}

\section{Definition:}

Type: Beaches, sandbanks and Sand Dunes Occupation

They are urban occurrences constituted in beach plains. They Extend as the road tissue expands and the soil subdivision, presenting poor infrastructure, compromising the site's environmental quality. They overlap areas of sandbanks, dunes and beaches, extinguishing local ecosystems. Sources of real estate dynamics, these urban structures are used as a product image and market of a lifestyle linked to leisure. It can be observed the creation of leisure spaces, hotel and vacation residences.

\section{Articulation structures:}

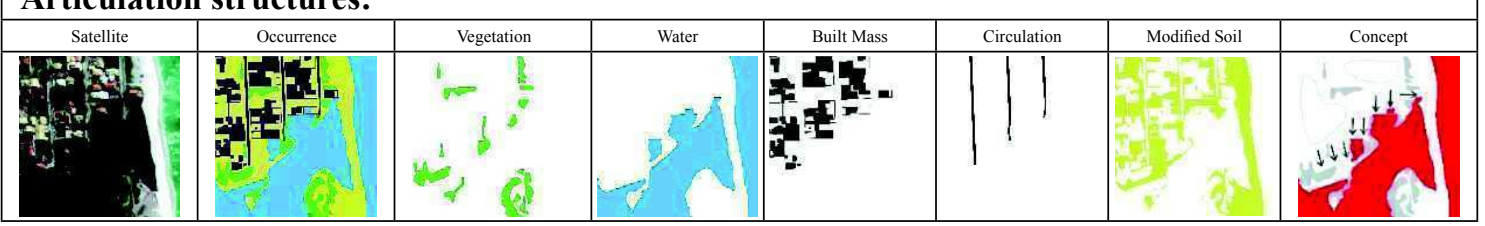

Figure 3.

Urban Occurrences, Group II.

\section{Definition:}

Type: Urban Settlements

Formed by urban mass consolidated in the physical space, with diversified and mixed use. Receives growth pressures continuously, favoring urban density, and the natural site elements. The urban density in the settlements is connected to a more complex hierarchical thoroughfarenetwork. Its informal growth causes the arrangement of residual spaces nearby they built mass.

\section{Articulation structures:}
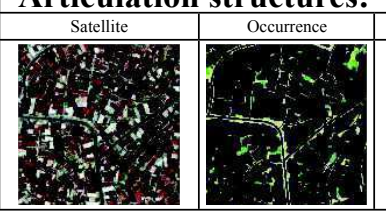

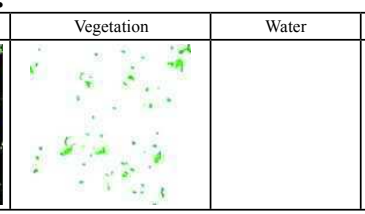
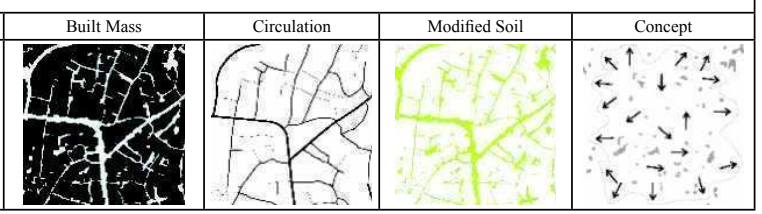
Type: Low Density Urban Settlements

\section{Definition:}

Urban formations previously delimited by road structures, lots divided into private fractions of different shapes through walls or land clearing. They have low vegetation due to deforestation of the initial land division. Different patterns of houses are noticed in the low-density portions, and lower standard houses in the parts where increases the density of the settlement. The settlements of informal buildings are characterized by the absence of infrastructure, irregular forms of occupations and new informal pathways, which consolidate in the denser spaces. They cause environmental damage, eliminating its natural resources and tend to become urban settlements.

\section{Articulation structures:}

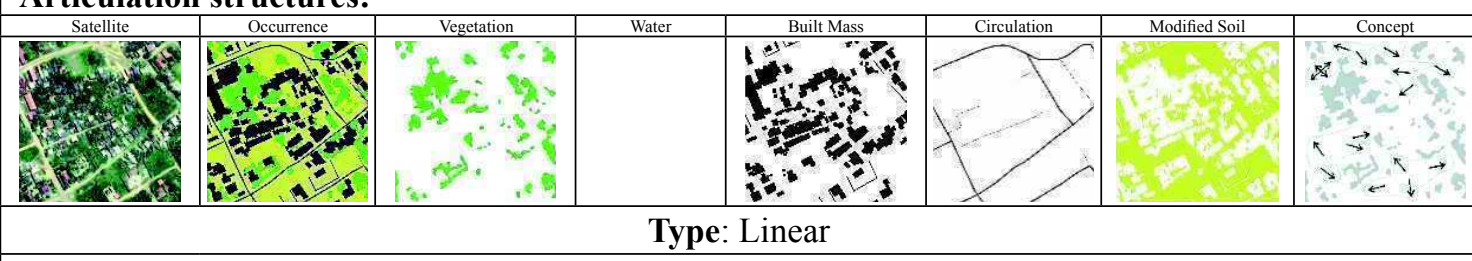

\section{Definition:}

Urban structures guided by a main access thoroughfare or through an important road flow in the urban tissue. Characterized by linear growth and its expansion at the back of the lot, also forming privatized spaces in condominiums. They also can consolidate between two strategic access points in the city, such as highways in parallel to the sea and beaches. In areas restricted to buildings, such as forests or the preservation areas.

\section{Articulation structures:}

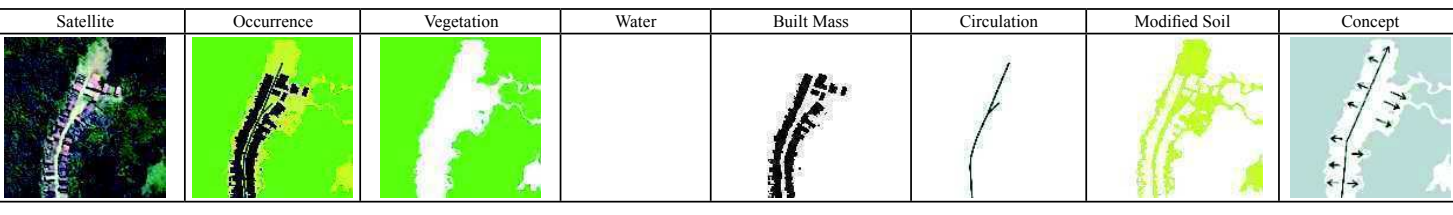

Type: Traditional Occupation

\section{Definition:}

Spontaneous and traditional lower density structures. They are accessed by main roads and internal pathways, connecting buildings and main points of the community. Characterized by occupying spaces in a rational way, allowing meeting points in the center and references for the community, such as beaches, rivers and lakes. There are examples of indigenous, quilombola and caiçara communities, among others that have in their forms of implantation, references of traditional communities.

\section{Articulation structures:}

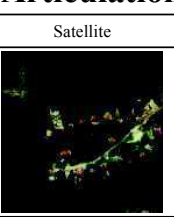

Occurrence

\begin{tabular}{|c|c|}
\hline Vegetation & Water \\
\hline &
\end{tabular}

Figure 4.

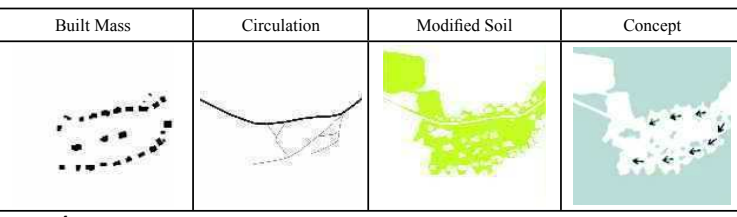

Urban Occurrences, Group III.

\section{Definition:}

Type: Settlements

Urban interventions of housing assistance promoted by the state. They present the form of sequential housing settlements with absence of places of leisure, squares and Green areas. They are deployed on lower-cost lands, in locations far from urban centers where basic infrastructure is precarious or absent, and on environmentally sensitive locations to the deployment of large settlements.

\begin{tabular}{|c|c|c|c|c|c|c|c|}
\hline \multicolumn{8}{|c|}{ Articulation structures: } \\
\hline Satellite & \begin{tabular}{|c|} 
Occurrence \\
\end{tabular} & Vegetation & Water & Built Mass & Circulation & Modified Soil & Concept \\
\hline 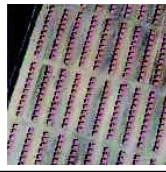 & 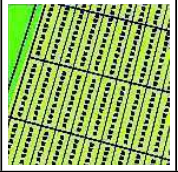 & & & HIIIII & $H+H$ & & \\
\hline
\end{tabular}




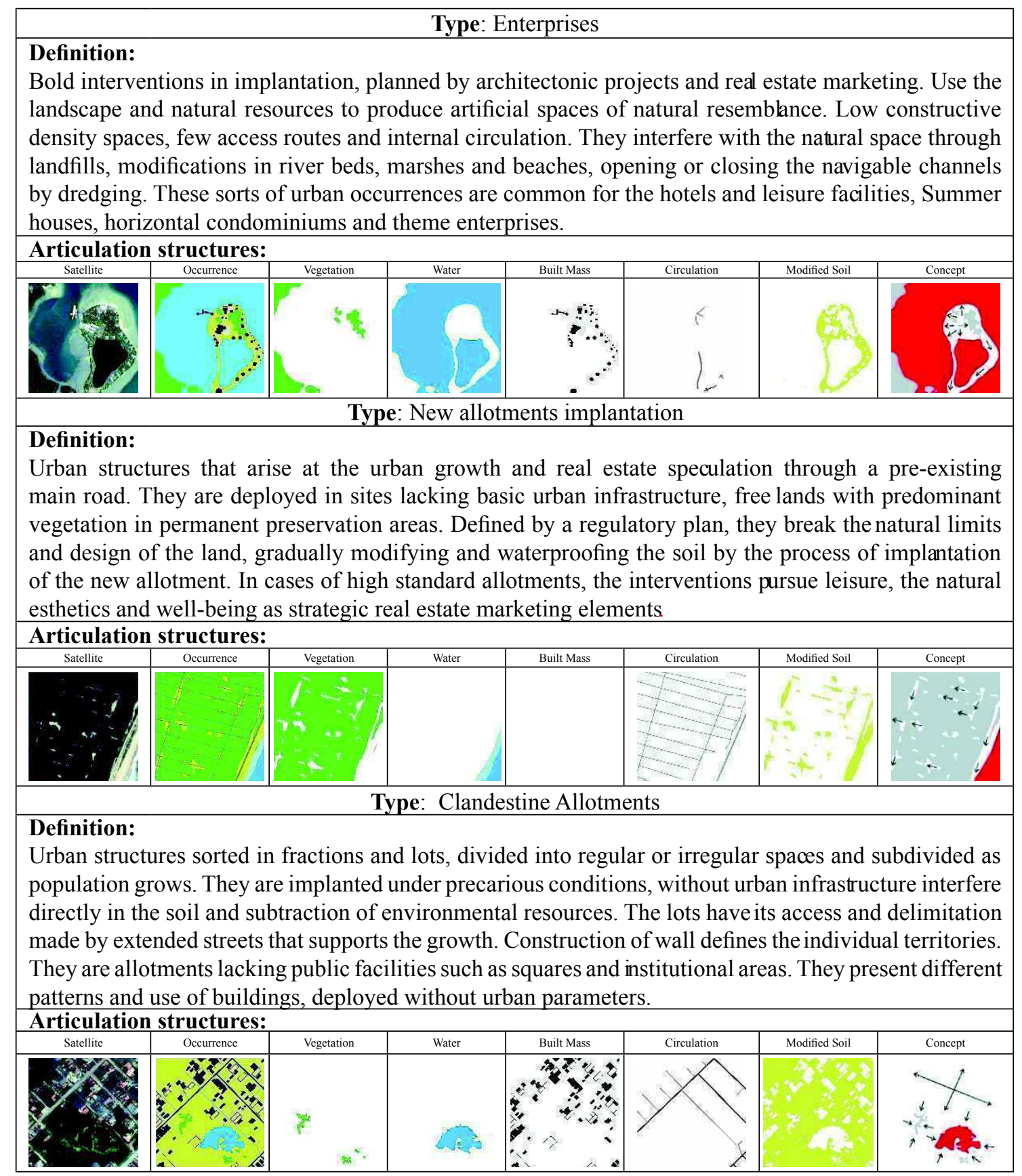

Figure 5.

Urban Occurrences, Group IV.

\begin{tabular}{|c|c|c|c|c|c|c|c|}
\hline & & & $\mathrm{Mi}$ & ecurrenc & & & \\
\hline $\begin{array}{l}\text { Definition: } \\
\text { Overlaps o } \\
\text { represented }\end{array}$ & $\begin{array}{l}\text { Irban occ } \\
\text { groups I, }\end{array}$ & $\begin{array}{l}\text { aces th } \\
\text { II, IV, c }\end{array}$ & $\begin{array}{l}\text { it th } \\
\text { ed in }\end{array}$ & $\begin{array}{l}\text { space. } \\
1 \text { forms }\end{array}$ & $\begin{array}{l}\text { rent } m \\
\text { observ }\end{array}$ & logical & gements \\
\hline Articulatic & tructures & & & & & & \\
\hline Satellite & Occurrence & $\begin{array}{l}\text { Vegetation } \\
\end{array}$ & Water & Built Mass & Circulation & Modified Soil & Concept \\
\hline & $7 \times 17$ & & & 7. & & & \\
\hline
\end{tabular}


are known by the contemporaneity in the cities they produce.

The result was the construction of an instrument of urban analysis through an analytical picture of the illegal urban form. This article enables to identify, analyze and direct the urban growth in cities with realities similar to the object of study.

\section{References}

Butler, R. W. the consept of a tourist área cycle evolution: implications for management of resources. Canadian Geografer, Ontario, v.24, n.1, p. 5-12, 1980.

Carvalho, Jorge. Formas urbanas. Coimbra: MinervaCoimbra, 2003.

Goitia, Fernando Chueca. Breve história do urbanismo. Madri, Alianza Editorial, 22.ed. 2001.

Instituto Brasileiro de Geografia e Estatistica, IBGE. <http://cidades.ibge.gov.br/xtras/ home.php> Access em 18 de jan. de 2017.

Instituto do Patrimônio Histórico e Artístico Nacional, IPHAN. Conjuntos urbanos tombados (cidades históricas). Brasília, 2015. Avaitable in:

$<$ http://portal.iphan.gov.br/pagina/ detalhes/123>. Access em: 15 abr. 2016.

Morris, A. E. J. Historia de la forma urbana: desde sus Orígenes hasta la revolución Industrial. Barcelona, Editorial Gustavo Gilli, 4. ed. 1992.

Panerai, Philippe. Análise urbana. Tradução: Francisco Leitão. Revisão técnica: Sylvia Ficher. Brasília: Editora Universidade de Brasília, 2006. (Coleção Arquitetura e Urbanismo).

Reis, Nestor Goulart. Notas sobre urbanização dispersa e novas formas de tecido urbano. São Paulo: Via das Artes, 2006.

Rolnik, Raquel. A cidade e a lei: legislação, política urbana e territórios na cidade de São Paulo. São Paulo: Studio Nobel: Fapesp, 1997.

Teixeira, Manuel C. A forma da cidade de origem portuguesa. São Paulo: Editora Unesp, Imprensa Oficial do Estado de São Paulo, 2012.

United Nations Educational, Scientific and
Cultural Organization, UNESCO. World Heritage List. Avaitable in: <http://whc. unesco.org/en/list/>. Access em: 19 jan. 2017. 